\title{
Demographic and migrational conditions in Torslev parish 1870-1901
}

By

Arne Vangdrup

University of Copenhagen

\section{Introduction}

The sources used to illustrate the demographic conditions in Torslev parish originate from the parish church books and from the population censuses of 1870,1880, 1890 and 1901. At the end of the 19th century these two sources were officially considered to be very reliable and random tests of the census information on birth places checked against birth lists in church books confirm this assumption. Data on emigrants are collected from the emigration lists that K. Hvidt has coded on magnetic tapes. Other data used are taken from statistical publications.

The material is analysed according to common historical research tradition, where general conclusions are drawn on the basis of unique information. Unlike the case in works on migration by, in particular, demographers and economists, the starting point was not an explicit research hypothesis but problems were investigated when they appeared during the course of the work - still with due attention to source conditions.

\section{Demographic conditions in Torslev parish}

The strong population increase which characterized Scandinavia during most of the 19th century is emphasized by migration researchers as the demographic background for the large-scale external and internal migrations of that period. This increase (the birth surplus) was due to a permanently high fertility and at the same time a strongly reduced mortality. The population increase 
Table 1. Absolute numbers of population increase, birth surplus and netmigration and the rates of migration, expected growth and actual growth in Torslev and in the land districts in Dronninglund herreda, Hjørring arnt and in Denmark.

\begin{tabular}{|c|c|c|c|c|c|c|}
\hline & $\begin{array}{c}\text { Popu- } \\
\text { lation } \\
\text { increase }\end{array}$ & $\begin{array}{c}\text { Birth } \\
\text { surplus }\end{array}$ & $\begin{array}{c}\text { Net } \\
\text { migra- } \\
\text { tion }\end{array}$ & $\begin{array}{c}\text { Rate of } \\
\text { niigra- } \\
\text { tion }\end{array}$ & $\begin{array}{l}\text { Rate of } \\
\text { expected } \\
\text { growth }\end{array}$ & $\begin{array}{c}\text { Rate of } \\
\text { actual } \\
\text { growth }\end{array}$ \\
\hline \multicolumn{7}{|l|}{$1860-70$} \\
\hline Torslev & 100 & 330 & 230 & 12,3 & 17,6 & 5,3 \\
\hline Dronn. hrd. & 2.806 & 3.415 & 609 & 4,0 & 22,6 & 18,6 \\
\hline Hjørr. amt & 7.302 & 12.262 & 4.960 & 6,1 & 15,2 & 9,1 \\
\hline Denmark & 109.534 & 146.737 & 37.203 & 2,8 & 11,4 & 8,6 \\
\hline \multicolumn{7}{|l|}{$1870-80$} \\
\hline Torslev & 197 & 358 & 161 & 8,0 & 17,7 & 9,7 \\
\hline Dronn. hrd. & 158 & 2.881 & 2.723 & 16,4 & 17,4 & 1,0 \\
\hline Hjørr. amt & 6.338 & 14.623 & 8.285 & 9,4 & 16,7 & 7,3 \\
\hline Denmark & 74.728 & 177.355 & 102.627 & 7,5 & 12,9 & 5,4 \\
\hline \multicolumn{7}{|l|}{$1880-90$} \\
\hline Torslev & 139 & 458 & 319 & 14,6 & 20,9 & 6,3 \\
\hline Dronn. hrd. & 284 & 3.469 & 3.185 & 19,0 & 20,7 & 1,7 \\
\hline Hjørr. amt & 4.576 & 17.100 & 12.524 & 13,5 & 18,4 & 4,9 \\
\hline Denmark & 30.483 & 192.735 & 162.252 & 11,4 & 13,5 & 2,1 \\
\hline \multicolumn{7}{|l|}{$1890-01$} \\
\hline Torslev & 165 & 572 & 407 & 15,8 & 22,2 & 6,4 \\
\hline Dronn. hrd. & 1.033 & 3.939 & 2.906 & 15,1 & 20,5 & 5,4 \\
\hline Hjørr. amt & 5.055 & 18.276 & 13.221 & 12,3 & 17,0 & 4,7 \\
\hline Denmark & 44.610 & 220.819 & 176.209 & 10,9 & 13,7 & 2,8 \\
\hline
\end{tabular}

Source: Torslev figures are taken from census lists and church books.; The population growth is taken from stat. tabelv., 5. rk., litra A, no 5, excluding Dronninglund herred, where information is taken from Trap 2., 3. and 4. edition.; The birth surplus is taken from stat. tabelv., 3 . rk., band 12 and 25. stat. tabelv., 4. rk., litra A, no. 1, 2, 5, 7 and 9. Stat. tabelv., 5. rk., litra A, no. 2.

a Torslev sogn is not included in Dronninglund herred.

was, however, not equally intense in all periods of the century. The population, for example, grew more strongly in the rural Danish districts before 1870 than it did in later years. The decrease during the Iast three decades is explained by the large out-migration from the rural districts which, after a sudden rise in the 1870 's, culminated during the following 20 years. $^{1}$ 


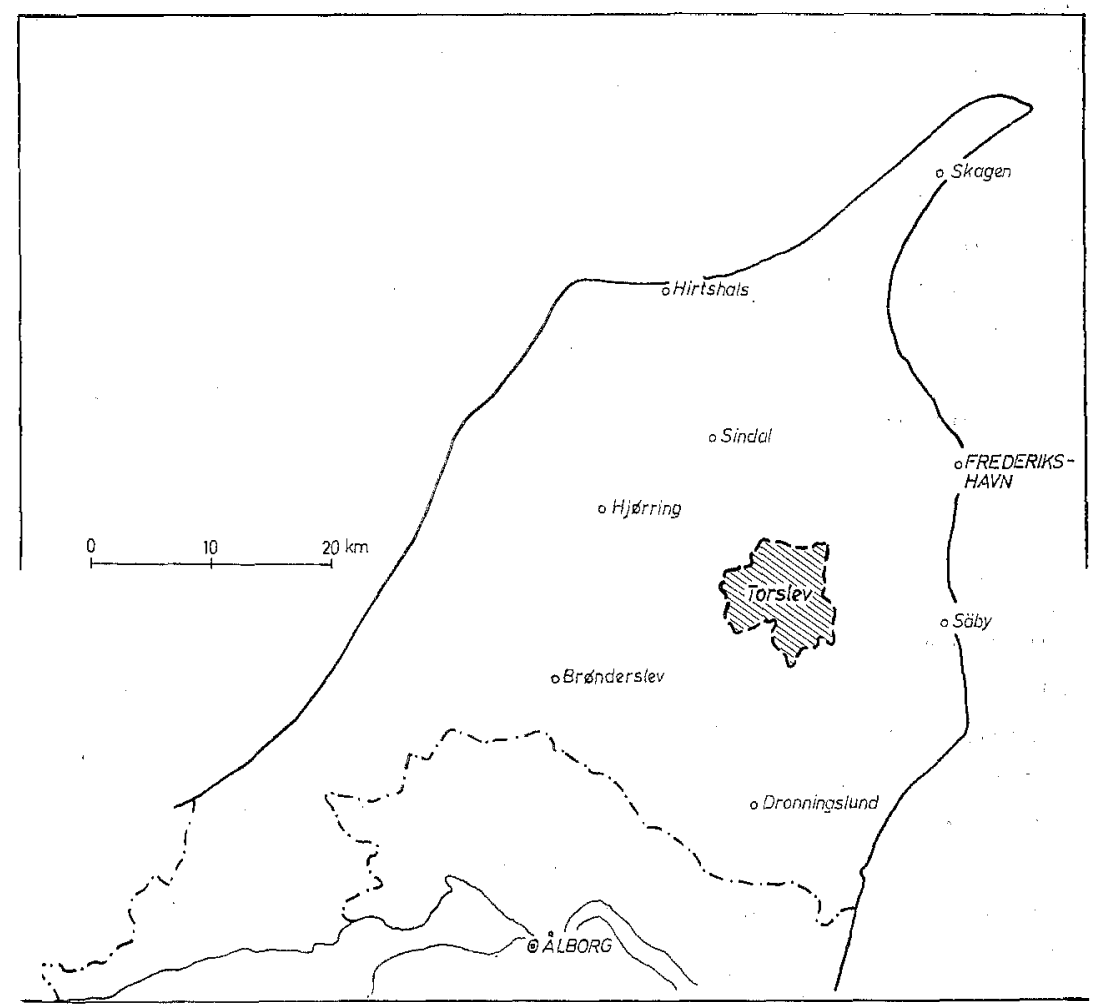

Figure 1. The investigation area.

The population development in Torslev parish and in Hjørring amts landsogne (county parish) showed the same growth, i.e. a stronger one in the 1870's than in the 1880's and 1890's. But unlike its macrolevels Torslev distinguished itself by the strongest population increase throughout the whole period 1870-1901 (rate of population increase in Table 1 ). ${ }^{2}$

The larger population growth and generally higher net-migration of Torslev compared with the other investigation areas must be based on the stronger birth surplus of the parish. The high level of birth surplus is namely due to a high birth frequency originating from a strong fertility - marital as well as extra-marital.

When we consider the age/sex relation in Torslev sogn and in the Danish rural population at the end of the 19th century, we find that the normal female dominance weakens throughout the period and males are even slightly over-represented in 1901. The sex balance in the countryside is due to the migration from country- 
side to cities, which is generally characterized by a female dominance. ${ }^{3}$

It is very remarltabie to find that there is such a surprisingly large number of girls in the age span of $0-14$ years. The explanation is, however, quite natural; many girls were born - in the 1870's the girls amounted to $52.5 \%$ of the births. Within the most mobile age groups (15-29 years) the men show a relatively larger variation than women between census years. Apart from these examples the age/sex relations show a great stability throughout the period: The age groups under 20 years of age are as slightly dominated by men as are the age groups above 20 years of age by women.

\section{The Emigration}

With an emigration intensity of 156 per 1000 inhabitants of the mean population during 1870-1901, Torslev has the highest measured emigration intensity of thk four investigation areas. ${ }^{4}$ Particularly in the 1880's the emigration is considerably Iarger from Torslev sogn which is due to a more time-concentrated emigration. More than $50 \%$ of the emigrants thus leave Torslev during this decade; in 1882 as many as 16\% left (Table 2).

The Torslev emigrants turn out to be different from Danish rural districts also regarding the age distribution. The mean age is the lowest in the parish and most marked for women. Torslev has

Table 2. Mean annual emigration in permille of the rural mean population of each period from Torslev sogn and the rural districts in Dronninglund herred, Hjørring amt and of the whole Denmark 1870-1899 (5-year and 30-year periods).

\begin{tabular}{lcccc}
\hline & $\begin{array}{c}\text { Torslev } \\
\text { sogn }\end{array}$ & $\begin{array}{c}\text { Dronninglund } \\
\text { herred }\end{array}$ & $\begin{array}{c}\text { Hjørring } \\
\text { amt }\end{array}$ & Denmark \\
\hline $1870-74$ & 3,1 & 3,9 & 2,8 & 2,0 \\
$1875-79$ & 1,8 & 2,9 & 1,7 & 1,0 \\
$1880-84$ & 10,0 & 6,6 & 4,3 & 3,1 \\
$1885-89$ & 7,4 & 4,6 & 3,7 & 2,4 \\
$1890-94$ & 5,8 & 4,4 & 3,8 & 2,6 \\
$1895-99$ & 2,6 & 1,1 & 1,3 & 0,7 \\
\hline $1870-1899$ & 5,2 & 3,8 & 3,0 & 2,0 \\
\hline
\end{tabular}

Source: The mean population is calculated from Torslev population censuses, Trap 2. and 3. edition and, Stat. tabelv., 5. rk., litra A, no. 5. table 6; Emigration figures from K. Hvidt's ADB material. 
namely got a larger amount of its trans-oceanic emigrants in the year spans under 15 years $(25 \%$ compared to a rural average of $18 \%) \cdot{ }^{5}$ As in other places the age span 15-29 years is numerically the strongest. This group makes up $60 \%$ of the emigrants from Torslev parish as well as those from Danish rural districts as a whole."

Although we cannot generally conclude that a large amount of children in the emigration is equivalent to a high family representation, this is the case for Torslev parish (and Hjørring county). Compared with the national average the parish has a surprisingly largefamily emigration, especially in the 1880 's and in the 1890's. In these two decades $55 \%$ and $47 \%$ respectively of the local emigration consisted of family groups while the country average was $39 \%$ and $30 \%$ resp. ${ }^{7}$ If this is added to the emigration intensity of the same two periods we find that the larger the emigration the larger the amount of families among the emigrants. ${ }^{8}$

As a consequence of the high family emigration it is natural that the amount of women is correspondingly high. Eliminating children under 15 years of age, we get the following sex distribution among 1000 Torslev emigrants: 595 men and 405 women compared to the Danish rural emigration of 648 men and 352 women. ${ }^{9}$ If the amount of women in each age group is examined on a national and parish basis we find that women are weakest represented in those age groups where the emigration is highest, i.e. from 15-29 years. The fact that the female representation is increased in the age groups over 30 years is only logical - they are now in "matrimonial ages".

Occupational distribution. The socio-economic occupational distribution shown in Table 3 is divided into five main groups. People with other occupations (aftegtsfolk, former landowners and cottagers supported by the new owner of their farm, and almisselemmer, paupers supported by the welfare relief) were excluded as well as individuals with no special occupation stated. The latter group also includes children under the age of 15 without occupation and women classified as wife, married, widow etc.

According to Table 3 the emigration was not a phenomenon which struck different classes equally hard. The emigration was chosen by the lower socio-economic groups to a much higher degree. Of the 192 Torslev emigrants represented in the Table, 86\% are from the assistant and labourer group compared to $50 \%$ of the population. ${ }^{\mathbf{1 0}}$ The second largest group is the journeymen etc., who, 
Table 3. The mean percentage occupational distribution on main occupations in the Torslev parish for the whole population, emigrants, migrants to market towns, and migrants to Skæve parish.

\begin{tabular}{lcccc}
\hline & $\begin{array}{c}\text { Parish } \\
\text { population } \\
1870-1901\end{array}$ & $\begin{array}{c}\text { Emigrants } \\
1870-1899\end{array}$ & $\begin{array}{c}\text { Migrants } \\
\text { to market } \\
\text { towns } \\
1870-1890\end{array}$ & $\begin{array}{c}\text { Migrants } \\
\text { to Skave } \\
\text { parish } \\
1870-1890\end{array}$ \\
\hline $\begin{array}{l}\text { Independents within agri- } \\
\text { culture (landowners } \\
\text { and cottagers) }\end{array}$ & 32,8 & 5,2 & 15,7 & 20,0 \\
$\begin{array}{l}\text { Independents outside } \\
\text { agriculture and civil } \\
\text { servants and officials }\end{array}$ & 4,4 & 0,5 & 1,4 & 5,0 \\
$\begin{array}{l}\text { Journeymen and workers } \\
\text { with a stated } \\
\text { occupation outside } \\
\text { agriculture }\end{array}$ & 12,2 & 8,3 & 5,7 & 7,5 \\
$\begin{array}{l}\text { Farm-hands, labourers } \\
\text { and others with no } \\
\text { special training }\end{array}$ & 6,9 & 27,1 & 2,8 & 7,5 \\
Assistants, i.e. servants & & & & \\
$\quad$ and maids & 43,8 & 58,9 & 74,3 & 60,0 \\
\cline { 2 - 6 } & 100,1 & 100,0 & 99,9 & 100,0 \\
\hline
\end{tabular}

Source: Torslev population censuses.

expressed as a percentage, have only slightly lower figures in the emigration than in the population as a whole. The same cannot be stated of the independent farmers who, according to Table $\mathbf{3}$, formone-third of the population but only $5 \%$ of the emigrants. The conclusion is then: Those who owned land felt no need to pin their hope on a more uncertain future on the other side of the Atlantic. When emigrants can be traced in a census it is possible to find a good deal of background information about them, which should be used for comparisons between the identified emigrant groups and the Torslev population.

In all, $41 \%$ or 134 out of 325 possible emigrants (Vejle emigrants excluded) could be traced in the Torslev censuses. They are calculated in percentages distributed on the three censuses $(1870,1880$ and 1890) corresponding to the percentage distribution of the emigration population on these three decades. Thus, by far the most are found in the 1880-census. 
Neither is there any difference of any note in the age distribution between identified emigrants compared to the total parish emigration, apart from the age group under 15 years. It is not unexpected that just this age span is under-represented among the identified emigrants since theoretically about ten years could have passed from the emigration to the preceding census.

Women's under-representation among the identified persons is also comprehensible, since a marriage then meant that the woman got her husband's name. If this change of civil status was performed between census and emigration an investigation is impossible, while concordance of names was essential for identification. The result was that $33 \%$ of the identified persons were women, compared to $40.5 \%$ of the total emigration.

When studying whether the Torslev emigrants had stronger mobility inclination than other parish inhabitants, we must turn to information about birth place in the censuses. The census states, namely, nothing about the number of a person's movements but a birth place outside Torslev might indicate a migration inclination. If we assume that this inclination was stronger for emigrants, then a large amount of them should have been born outside the parish.

Table 4 illustrates that the percentage of Torslev-born among identified emigrants is larger than among the whole population, which means that previous migrants were not especially inclined to emigrate.

Since there is, however, a lack of information about $60 \%$ of the emigrants the general value of the conclusion is dubious, Thus it must be expected that identified emigrants are found in the census to a Iarger extent just because they were generally born in the parish

Table 4. Identified emigrants and the population of Torslev distributed on birth places, per cent.

Torslev

Emigrants

population

Torslev parish

\begin{tabular}{rr}
63 & 53 \\
20 & 18 \\
14 & 23 \\
3 & 6 \\
\hline 100 & 100
\end{tabular}

Source: Torslev population censuses. 
and probably lived there most of their lives, in contrast to those who were not identified.

On the basis of census information some of the identified emigrants were more closely investigated concerning the familial and ocial background in Torslev. To obtain a statistical material to work with, we chose emigrants registered as single, who were below the age of fifteen at the census counting and who lived with their parents. These criteria were fulfilled by 48 individuals, i.e. one-third of all identified persons or $15 \%$ of all emigrants. It could be estabished from the census lists whether these children originated from Ereeholds or smallholdings in the parish, but a further specification 3f the size of acreage could not be made.

As is shown in Table 5, the emigration inclination of freeholders' and smallholders' children fully corresponds to the distribution of the two farming types. There is, thus, no tendency for children from richer homes to dominate or vice versa among the identified emigrants.

If we then look at the emigrants' consecutive child order in her/ his family the census can only partly answer this question. We cannot be certain that all children were present at their parents' home at the census, since children above the age of 15 usually worked away from home.

The eldest child will therefore be over-represented in the material, although correspondingly so for both freeholders' and smallholders' children. The result of the comparison was that there were twice as many first-born emigrants originating from smallholdings as there were first-born of freeholders $(44 \%$ and $21 \%) .11$

Table 5. Emigrants registered as single and migrants to market towns and Skæve parish originating from freeholds and smallholdings in Torslev Parish, and the parish distribution of freeholds and smallholdings in per cent.

Emigrants $\begin{gathered}\text { Migrants to } \\ \text { market towns }\end{gathered} \quad \begin{gathered}\text { Migrants to } \\ \text { Skæve }\end{gathered}$ Torslev parish

Freeholders'

children

Smallholders'

children

\begin{tabular}{rrrrr}
29,0 & 34,0 & 21,0 & $\begin{array}{l}\text { Free- } \\
\text { holds } \\
\text { Small- }\end{array}$ & 29,6 \\
71,0 & 66,0 & 79,0 & holds & 70,4 \\
\hline 100,0 & 100,0 & 100,0 & & 100,0 \\
\hline
\end{tabular}

Source: Torslev population censuses. 
The explanation might be the different future prospects of the two "types of children". While a freeholder's first-born (boy) could count on a secure future as head of an inherited farm, a possible future as a smallholder or even just a house-owner was no great expectation for the younger children. Their future lay in the West their destination was the fertile and vast areas of the prairie.

\section{Torslev Parish Migrants}

The Danish censuses with information about birth place give us a limited possibility to trace migrants from an area. The only indication of a migration between 1870 and 1890 is a discrepancy between census place and place of birth. In the 1901 census two new entries were introduced. Information on "last residence before in-migration" states one station on the journey, while the entry "year of permanent residence" provides a basis for calculation of the age at migration. It is impossible to find every out-migrant from Torslev parish. Research procedure has therefore been to only interpret certain census material chosen in advance. Thus, persons giving Torslev as their place of birth (1870-1901) or as '(last residence" in 1901 were thereafter filed and used in the study.

On the basis of the rural population's strong orientation towards urban districts at the end of the 19th century, it seemed relevant to analyse Torslev-migrants who settled in the four market towns in the county between 1870 and 1901. The analysis of censuses in Sæby, Frederikshavn, Skagen and Hjorring was extended to aIso cover the railway parish/town (Vester) Bronderslev due to its explosive growth. Outside Hjørring county the large market town of Alborg and its northern offshoot Nørre Sundby was studied.

Since the characteristics of in-migrants to the market town only could be compared with those of the emigrants, it was necessary to also include out-migration to an agrarian district in the study. The neighbourinq parish Skæve was chosen since it resembled Torslev in population growth and emigration intensity etc.

Of a studied material of 152417 individuals, 1060 originated from Torslev. When double counts between the censuses are excluded we find that the town-dwellers numbered 557 different persons compared to 310 in Skæve parish. To find out which of the three decades the Torslev-born out-migrants moved to market towns or to country parishes we must exclude the double counts in each 
a. The migration rates in Table 6 include, apart from out-migrants towns and parishes, also the emigrants from the parish.

The table shows that throughout the period there is a continuously owing stream towards urban areas. Even in the 1880's, when the igration culminates, the attraction of the towns is increasing. A ect connection between emigration and market town migration not shown in the survey. The migration to Skæve is, on the other nd, influenced by emigration. In the 1880's the amount of rslev-born decreased and this trend remained until the $1890^{\circ} \mathrm{s}$ ien the emigration wave started to diminish. On average, a future a town-dweller was more tempting than their wish to leave the untry. The migration to adjacent parishes must, however, have en the largest since only $127 \%$ of the whole period's mean pulation went to one of the five neighbouring parishes. In ation to the different rates of each market town, the migration ttern changed according to the parish's town migrants. The itribution of Torslev-born living in towns is almost unchanged in 80 compared to 1870 but during- the 1880 's there is a marked ference. More than $80 \%$ of the parish's urban in-migrants settle the Hjørring towns, which increased their population by $41 \%$ ring this decade. In the 1890 's this growth falls to $26 \%$ and the lount of Torslev-born to $58 \%$. The stream now leads farther ray, to the towns of Alborg and Nørre Sundby, which showed a pulation growth of $64 \%$ during these eleven years.

The age at migration of all the out-migrants can be found for 1901 we use the census list information of birth date and year of gration. The comparison in Table 7 with age at emigration must considered under the reservation that the information extends er the whole period.

The crude and uneven age grouping in the table reveals great ferences in age at migration. As a rule the mobility is greatest long 15-29 year-olds, especially among market town in-migrants $\mathrm{d}$ emigrants. The age span $30-49$ is strongest represented in the æve in-migration and weakest in the emigration. Over the age of the inclination to migrate is very reduced, especially concerning ig-distance moves.

When the mobility is large for the family age group 30-49 years esults in a correspondingly large number of children, which is the se for Skæve parish. But can the lower share of children among trket town in-migrants in comparison with emigrants be extined despite their dominance in these towns? Is this due to a 
Table 6. Migration rates for Torslev-born living in market towns and Skæve, and the emigrants from the parish per mille of the mean population in Torslev parish in each period.

\begin{tabular}{lccc}
\hline & $\begin{array}{c}\text { In-migrants to } \\
\text { market towns }\end{array}$ & $\begin{array}{c}\text { In-migrants to } \\
\text { Skæve }\end{array}$ & $\begin{array}{c}\text { Emigrants Crom } \\
\text { Torslev }\end{array}$ \\
\hline $1870-1879$ & 51,8 & 33,6 & 24,2 \\
$1880-1889$ & 62,0 & 23,7 & 87,0 \\
$1890-1900$ & 76,3 & 36,7 & 42,2 \\
\hline $1870-1900$ & 236 & 127 & 156 \\
\hline
\end{tabular}

Source : Torslev population censuses.

Table 7. Distribution in per cent of age at migration for Torslev out-migrants to market towns, Skreve and abroad, and the mean age distribution of the Torslev population in 1870-1901.

\begin{tabular}{lcccc}
\hline & $\begin{array}{c}\text { Torslev } \\
\text { population }\end{array}$ & $\begin{array}{c}\text { In-migrants to } \\
\text { market towns }\end{array}$ & $\begin{array}{c}\text { In-migrants to } \\
\text { Skæve }\end{array}$ & $\begin{array}{c}\text { Emigrants } \\
\text { from Torslev }\end{array}$ \\
\hline $0-14$ & 39,2 & 20,7 & 29,6 & 24,5 \\
$15-29$ & 24,5 & 54,3 & 34,8 & 60,4 \\
$30-49$ & 19,8 & 21,5 & 27,4 & 10,4 \\
Over 50 & 16,6 & 3,5 & 8,1 & 4,7 \\
\hline & 100,1 & 100,0 & 99,9 & 100,0 \\
\hline
\end{tabular}

Source : Torslev population censuses.

high marriage rate with many children among emigrants aged 20-29? The material offers an indirect answer only to the last question. The lists lack information on civil status, but the entry of profession registered married women as wives and by using this we can see how many children married women brought with them. By comparing this average (2.4) with the corresponding one for married women's share of children when moving to towns (1.7), we find the explanation that emigrating wives on average had more children than women who migrated into towns.

The inclination of different age groups to migrate had a great influence on the age distribution of the birth parish: Children and the over-fifties are much fewer in the migration, while the opposite is the case for the age groups 15-49 years. The fact that the maintenance burden grows in the 1880's harmonizes well with the huge migration rates in this decade - a migration with a high mobility intensity into market towns and abroad (Tables 1 and 6). The 
xplanation of a minor maintenance burden during the 1890's in pite of a larger migration rate in this period (Table 1) must be een against the background of a changed migration pattern Table 6). The in-migration to other country parishes and market owns is increased while the emigration is reduced. ${ }^{12}$ And since the nternal migrants do not show the same one-sided age distribution s the emigrants, the age structure in Torslev parish is not as adically influenced as previously (Table 7).

The sex distribution of all internal out-migrants above 14 years of tge from 1870 to 1901 in Torslev parish shows us that women lominate, although only slightly, the migration to towns. Women nake up 517 and men 483 per mille of town in-migrants, whereas migrants have the inversed distribution. The sex distribution for kxæve in-migrants is almost equal: 491 women and 509 men per nille.

The familial and social background of the internal out-migrants from Torslev parish was also closely investigated. ${ }^{13}$ Table 5 shows that nore freeholders' children than smallholders' children prefer a uture life in towns to the wellknown hardships of countryside lifeThe high percentage of freeholders' children in the town innigration is made up of the freeholders' daughters, whose share of $6 \%$ in this migration clearly exceeds the $42 \%$ they account for in he Skave in-migration. The corresponding figures for smallnolders' daughters are $48 \%$ (town in-migrants) and $44 \%$ (Skave n-migrants).

A similar relative difference can be found in the distribution between the sons of smallholders and freeholders. The freeholders' ons are more orientated towards emigration than smallholders' ons. The explanation might be economic, since freeholders' children must have had easier access to money for the departure fee han smallholders' children. In the town in-migration the proporion between freeholders' and smallholders' sons equals the proporion between the two owner types in the parish. Least tempting to 'reeholders' sons is the prospect of migration to another agrarian parish.

Comparison of migrants' stated occupation in the market towns and in the Skæve material with their social background in Torslev parish does not reveal any difference between daughters of freeholders and smallholders. Both in the towns and in Skæve parish between $50 \%$ and $60 \%$ worked as house-maids (or servants), while most of the others statcd their civil status to be "married". 
Freeholders' and smallholders' sons, however, differed concerning occupations. Of the freeholders' sons who migrated to Skæve parish, $40 \%$ worked as assistants, while nearly $75 \%$ of the smallholders' sons belonged to this category. ${ }^{\mathbf{1 4}}$

More than $50 \%$ of the freeholders' sons were now found in the group of independent farmers and, it should be noted, as freeholders themselves. None of the smallholders' sons were registered as independent farmers. Most of them worked as farm-hands. The tendency is the same in the town in-migration. While $25 \%$ of the freeholders' sons are found in the assistants and labourers category, the corresponding figure for the smallholders' sons is $64 \%$. In the group of independents outside farming we found $25 \%$ of the freeholders' sons as compared tp $10 \%$ of the smallholders' sons. The material also indicates that in all cases more freeholders' sons than smallholders' sons took an education in the towns. Thus $30 \%$ of the first mentioned group were registered as apprentices compared to $10 \%$ of the latter group.

In conclusion: Freeholders' sons in Torslev parish got a higher socio-economic status than sons of less well-to-do smallholding parents. Most of the farm-hands and assistant group in the agrarian society as well as the proletariat in the rapidly growing towns were recruited among children of parents within the same socio-economic class.

\section{Numbers of Migrations and the Migration Pattern of the Torslev Parish Internal Out-Migration}

The Danish census material does not help us very much as regards how many migrations an individual performed before the year of 1901. In 1901 we can get more information, since by comparing birth place with last residence before the migration to the registration area we can get two migrations noted. There is, however, little hope of finding individuals who are registered for several migrations even before 1901. This is the case when a family is registered together. If we here use the information about a child's birth place (providingit differs from the parents' birth place as well as their last place of residence) it proves that the family had been domiciied in other places. In the 45 cases where the latter method gave a positive result, the persons are included in the migrants' number of moves and in the determination of the migration pattern. 
In all, 511 of the Torslev-born moved to market towns between 1870 and 1901 . The material only enables us to establish one move for $60 \%$ of them. The remaining 206 persons had moved from two to five times. Short-distance migration to the neighbouring parish Skave differs. The majority, e.g. nearly four-fifths, have one migration registered, while the remaining one-fifth showed from two up to five migrations.

An accurate picture of the out-migrants' distribution on indirect or direct migration to the registration area can only be established with the help of the 1901 census. The investigation showed that $60 \%$ of 217 market town in-migrants move indirectly to the town, which means that the last residence before the town settlement differed from their birth place in Torslev. The percentage differs of course, from town to town. Only in the short-distance migration of $11 \mathrm{~km}$ to the market town of Saby can we find a predominance of $60 \%$ direct movements, while the share of indirect movements increase in proportion to the distance from the birth place. Alborg, Nørre Sundby and Skagen are therefore highest with $71 \%$ indirect migration. The Skæve in-migration is, of course, characterized by a direct migration although more than $30 \%$ arrived at the parish indirectly. Men and women are, on the whole, equally distributed on the two migration patterns, to towns as well as to Skæve parish.

If we transfer the respective percentage to the total population of the period on the basis of the 1901 census distribution on indirect or direct migration to market towns, we find that the migration pattern for 203 Torslev-born is carried out directly and that 308 have moved indirectly. Of a theoretical number of 308 individuals, however, the material accounts only for 160 , who are divided into 131 individuals from the 1901 census and 29 determined with the help of the child's birth place. These indirect migrants can be more closely analysed in order to find out whether the migration into urban districts was performed by stages. If so, the out-migration area must be nearer to the market town than the birth place.

Table 8 shows that $58 \%$ of indirect town in-migrants move to areas closer to the town than to their birth place Torslev. There is thus a tendency of migration by stages. $28 \%$ arrived in the town from a place of residence situated farther away from the registration area than Torslev, but of them $65 \%$ come from one of the investigated market towns. Half of the persons whose place of residence and birth place is calculated to be at the same distance from the town, also have a market town stated as place of last residence. 
Table 8. Percentage distribution on the length of indirect migrations into the market town for Torslev-born out-migrants.

Market towns

The out-migration area is situated closer to the market town

than Torslev

57,5

The out-migration area and Torslev parish are situated at

the same distance from the market town

14,4

The out-migration area is situated farther away from the

market town than Torslev

28,1

100,0

Source: Torslev population censuses

The material thus indicates that migrations into market towns over long distances are performed by persons who previously lived in urban areas. The circulation between towns must have been enormous when one-third of all Torslev-born indirectly came from one market town to another..$^{1 \tilde{T}}$ The in-migration distances into each town do not differ much from those given in the table. Only the towns situated farther away, Alborg and N. Sundby, showed an expected dominance of in-migrants from a parish more adjacent than Torslev.

\section{The Background of the Demographic and Migrational Conditions in Torslev Parish (Conclusion)}

The generally larger birth surplus of Torslev parish during the period 1870-1901 compared to other population units meant that, parallel to a stronger population growth, the parish also had a high migrational rate (Table 1). The net out-migration was especially large after 1880 , when on average 15 per mille of the mean population annually left the parish.

The increase of out-migration intensity in the 1880s was a result of the internal migration into market towns, but more especially the transatlantic emigration (Table 6). In the 1880's Torslev parish reached an emigration intensity that clearly exceeded that of other investigation areas (Table 2). The fact that the out-migration rate further increased during the 1890's is not primarily due to the emigration extent, whereas the more extensive circular migration to other rural parishes showed a great increase at the same time as the market towns attracted still more parish children (Table 6). The wish for migration was strongest in the age group 15-29 years, 
tlthough the age at migration varied somewhat according to the lestination area (Table 7). Thus proportionally more productive roung persons went to towns or abroad than to neighbouring Jarishes, which had consequences for the age distribution of the Torslev population in the 1890 census. The maintenance burden rad heavily increased after the huge emigration wave of the preseding decade. The fact that the maintenance burden slackened during the period 1890-1901 is, among other things, due to the :hanged character of the out-migration. The short-distance migration was not as age-concentrated as the emigration.

Why then, did fairly young potential breadwinners leave their parish? And why to a greater extent, not until the 1880's? Was it tue to occupational problems and a consequence of difficult social conditions? A closer analysis of the relation between supply and demand for labour in the parish could not be directly made on the basis of the source material in question. However, we may assume that the prospect of getting a freehold or a smallholding of one's own was practically non-existent.

The fact that Torslev parish had a large pcpulation growth throughout the 1870's harmonizes well with the immense increase of the number of Iandless cottages up to 1885 . Hence, Torslev could support many breadwinners during this period, but from the beginning of the 1880's the possibility to become established in the parish must have diminished. Only very few and minor farms were allotted and a settlement in the Torslev society now meant that most young people of marital age had to be content with a small piece of land and that they had to increase their income by taking day-work and/or set up as journeymen.

Under these circumstances emigration or settlement in a town must have appeared as a realistic alternative in order to improve the social situation. The analysis of the parish's migrants also confirmed that it was the landless that moved away.

Their choice of destination divided freeholders' and smallholder's children from each other. Freeholders' children were more inclined to move to towns and abroad than to another rural parish, while the reverse is true of smallholders' children (Table 5).

The material thus indicates that freeholders' children considered their chances to avoid social degradation as being better if they left their rural environment. The investigation, however, shows that they were not completely correct in their judgement. 'When we followed the careers of some of the freeholders' and smallholders' 
children in the receiving areas, we did not find that they had better opportunities to avoid social degradation in an urban society than in the rural society. On the other hand, the investigation also showed that in comparison with sons of smallholders all freeholders' sons got better economic conditions both in Skæve parish as well * as in market towns. Most of the sons of smallholders remained in the assistant and labour group.

\section{NOTES}

1 Stat. tabelv., 5. rk., litra A., no. 5, Table 13.

2 The rates in Table 1 show the annual increase in per millc of the mean population of each of the four periods.

3 Stat. tabelv., 5. rk., litra A, no. 5, p. 48.

4 During the period 1868-1899 340 emigrants were registered from Torslev parish. All of them were found by means of the data strips that were prepared for Kristian Hvidt in connection with Flugten til Anzerika eller Drivekraefter $i$ masseudvandringen 1868-1914., Århus 1971.

5 In all 15 Torslev emigrants are registered in the Vejle records and they have therefore no information about names and ages.

6 Hvidt, op. cit., p. 154.

7 The mean country figures include both urban and rural districts. Hvidt, op. cit., p. 196.

8 The same conclusion in Hvidt, op. cit., p. 197 and in Andres A. Svalestuen, "Nordisk emigrasjon. En komparativ oversikt" in Emigrationen fra Norden indtil 1. Verdenskrig. Rapport Til Det Nordiske Historikermode i Kobenhavn 1971, 9-12 August. Copenhagen 1971, p. 44.

9 Hvidt, op. cit. p. 178.

10 Assistant and worker groups form 69\% of the whole Danish emigration. Hvidt, op. cit. p. 238.

11 The calculation includes both sexes. If the figures for boys and girls are separated we find that girls from both freeholds and smallholdings are placed in the group eldest child to a higher degree than boys. Of 13 identified girls 8 are an eldest child i.e. more than $60 \%$. The corresponding figure for eldest sons is below $30 \%$ (10 out of 35 ). - When we only look at the emigrating sons distributed on freeholds and smallholdings the result is still twice as many smallholders' sons in the eldest child group (36\% to 15\%).

12 The Skæve material is assumed to be representative for short-distance migrations to neighbouring agrarian parishes.

13 The material only includes single registered out-migrants to market towns and Skzve parish, who at the census were below 15 years of age and lived with their parents in Torslev parish. These criteria were fulfilled by 114 market town in-migrants and 57 Skæve in-migrants. This is about one-fifth of all registered internal out-migrants.

14 The occupational distribution is according to the one used in Table 3.

15 According to Sune Akerman these migrations are called circular, as opposed to the so-called effective migrations which refer to migrations from a rural parish to a market town. Sune Akerman, "Intern befolkningsomflyttning och emigration" in Emigrationen fra Norden indtil 1. Verdenskrig. Rapporter Til Det Nordiske Histoikermode $i$ Kobenhavn 1971, 9-12 August. Copenhagen 1971, p. 105.

16 The enlargement of the farming acreage took place between 1881 and 1888. Stat. Tabelv., 4. rk., litra C, no. 4, pp. $60 \mathrm{f}$ and no. 7, pp. $94 \mathrm{f}$. 


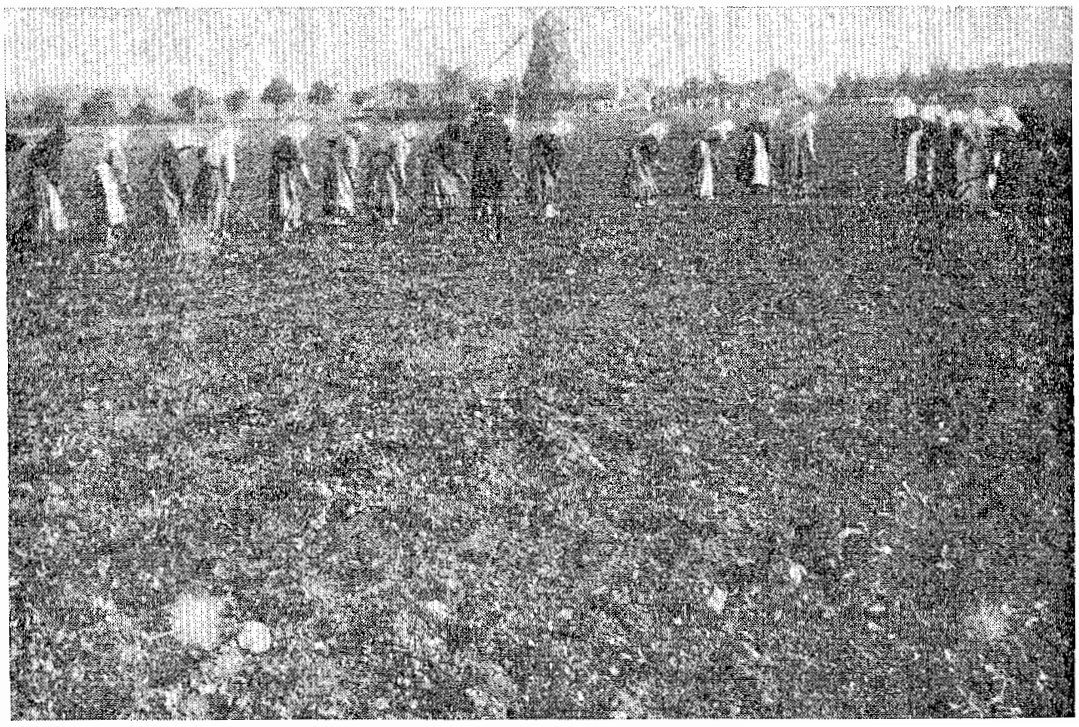

Work in the sugar beet fields in south Sweden, Emigrantinstitutet, Växjö.

The economy in the Nordic countries was still dominated by agriculture at the turn of the century.

A farm-hand's living quarters with an emigrant poster, Emigrantinstitutet, Vaxjo

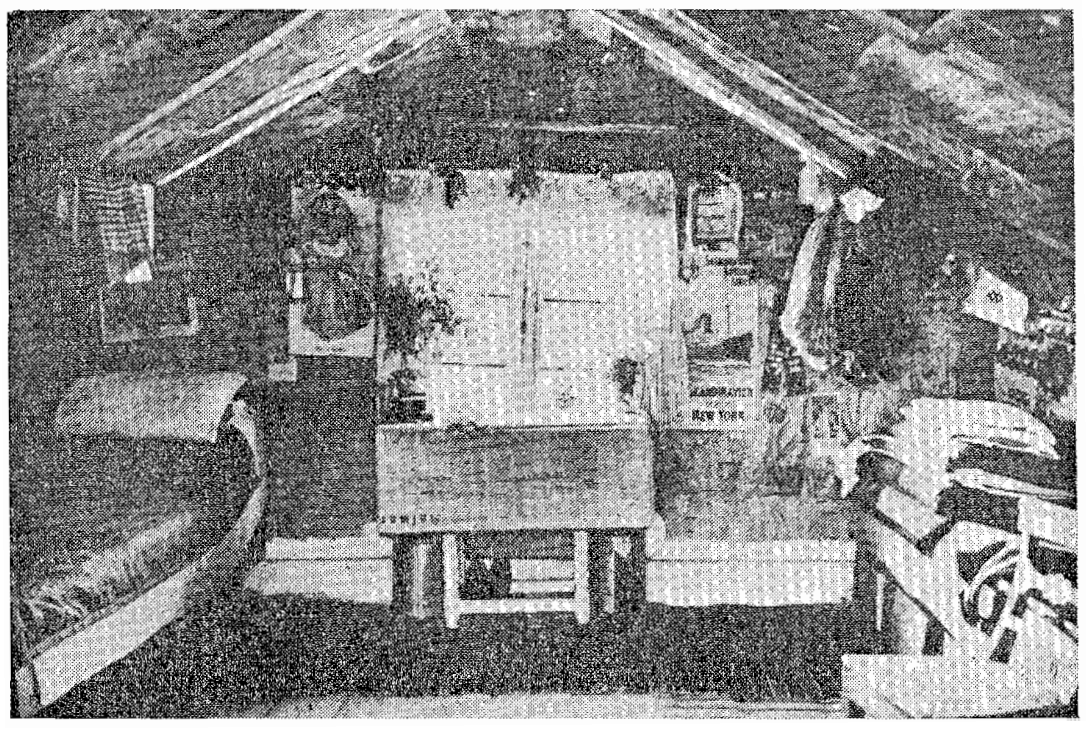




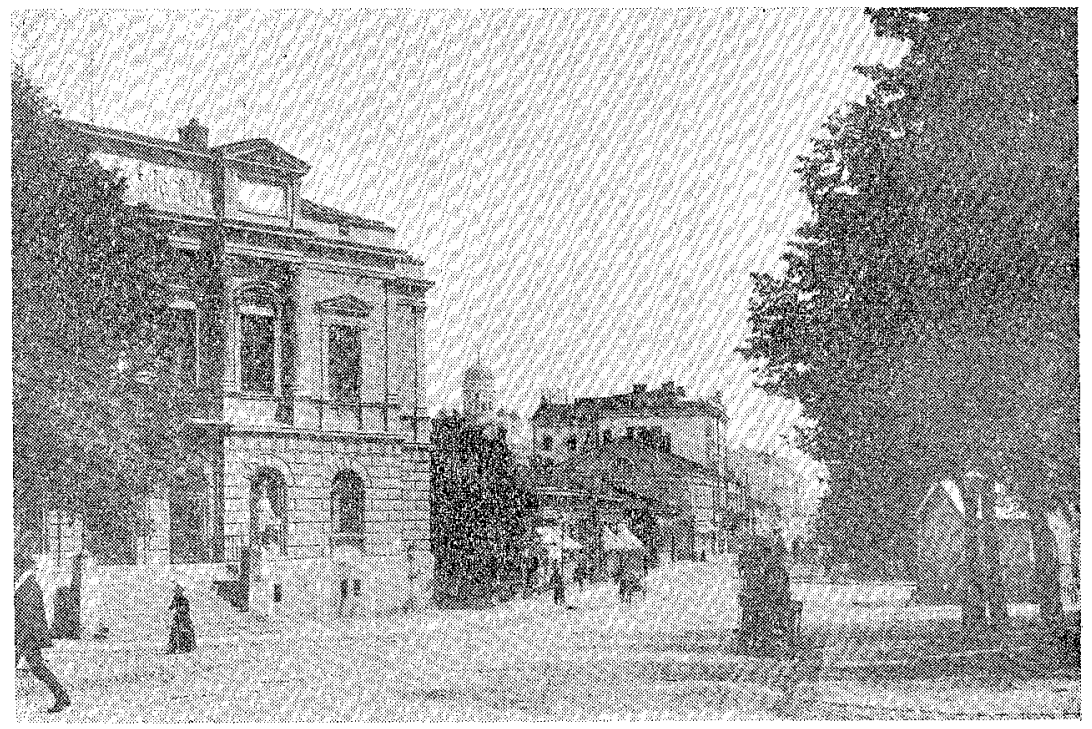

A street (Alexandergatan) in Helsinki at the beginning of this century. Nordiska muséet. Stockholm.

Industry in the Nordic countries started to expand strongly in the mid-1800s.. .

View from Copenhagen 1904. Nordiska muséet, Stockholm.

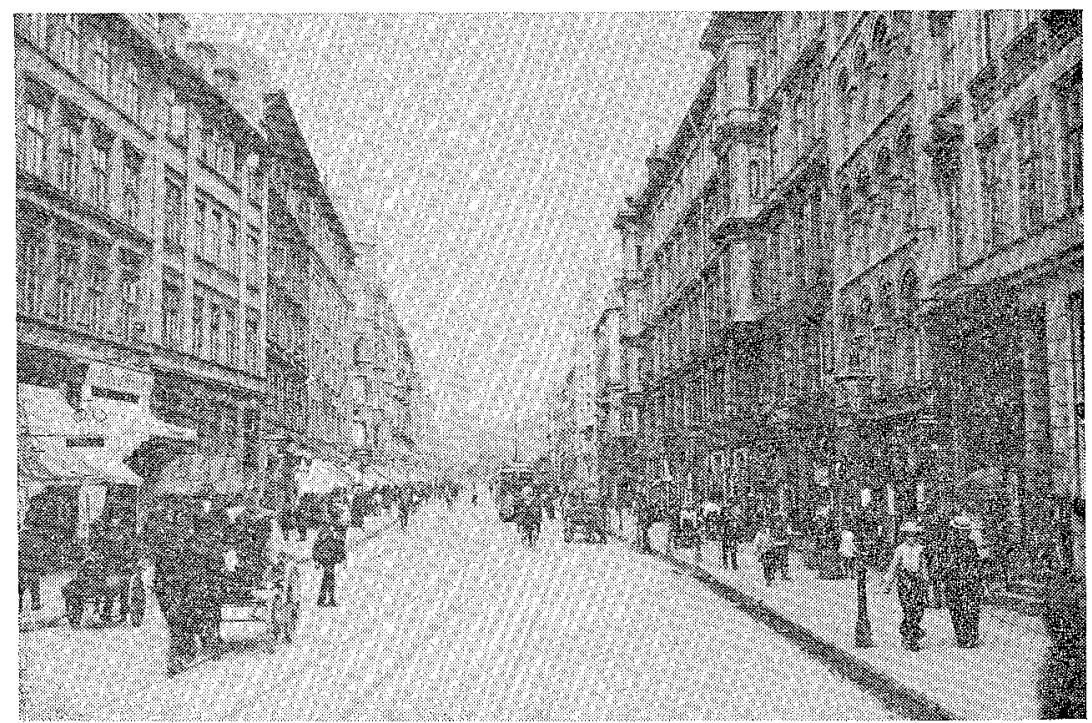




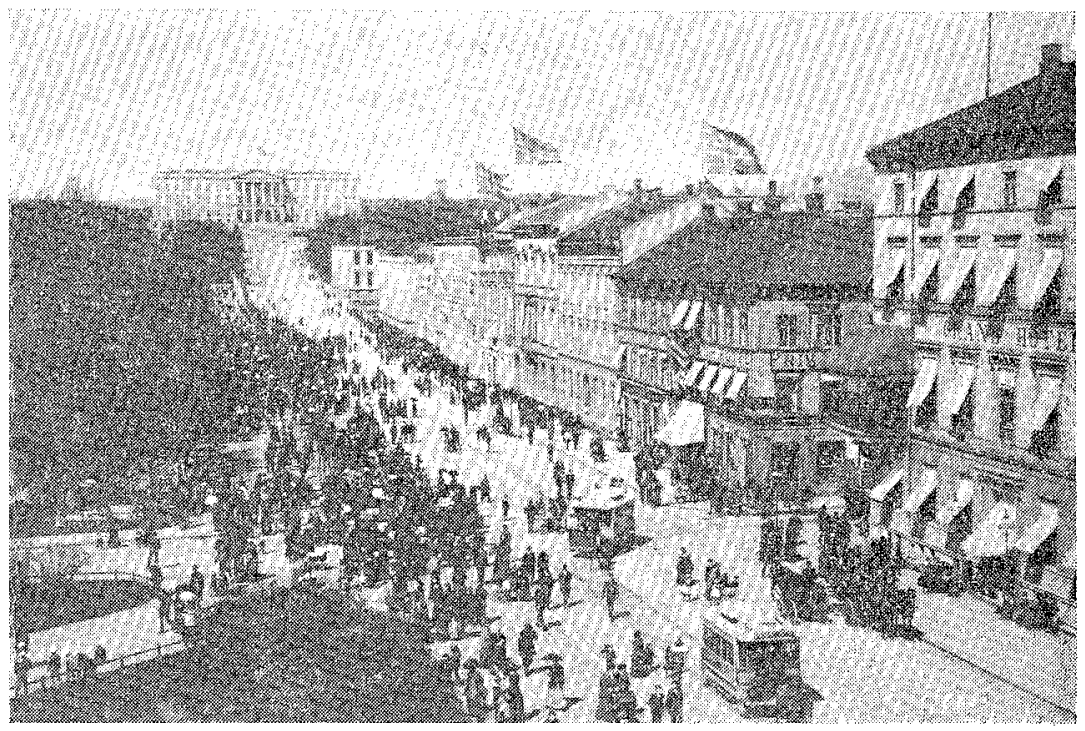

The main street in Kristiania (Oslo) 17 May 1900. Nordiska muséet, Stockholm.

... which also resulted in more people moving into the towns.

Sillgatan - 'Emigrant street' in Gothenburg. Emigrantlnstitutet, Vaxjo.

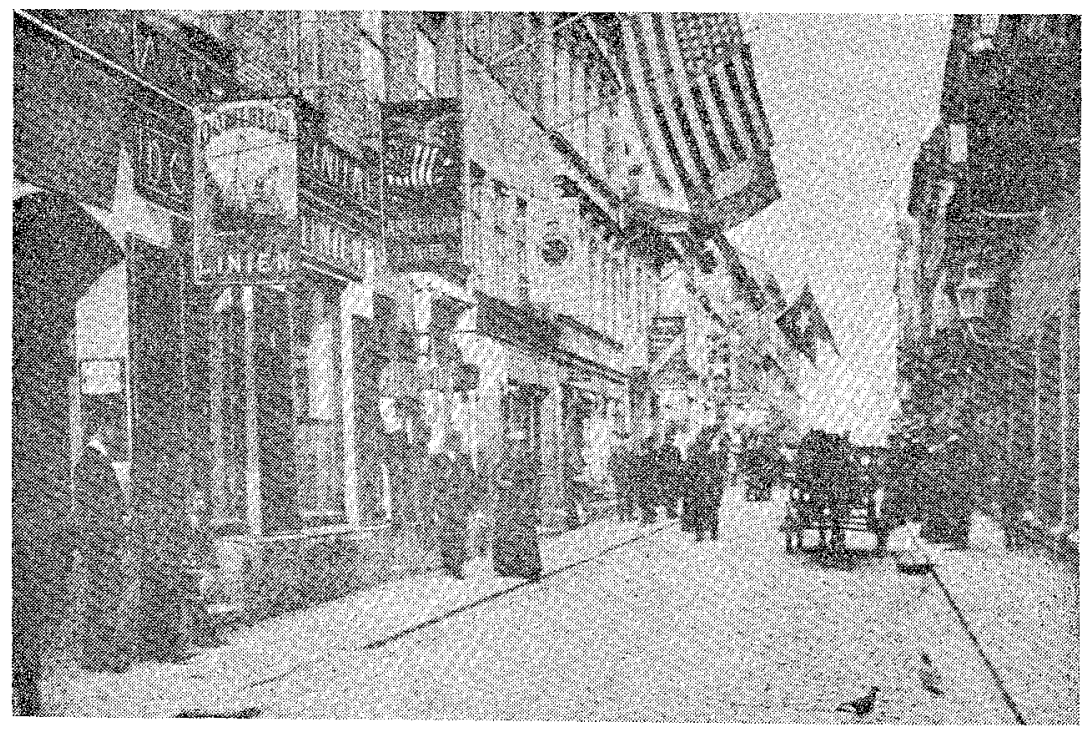




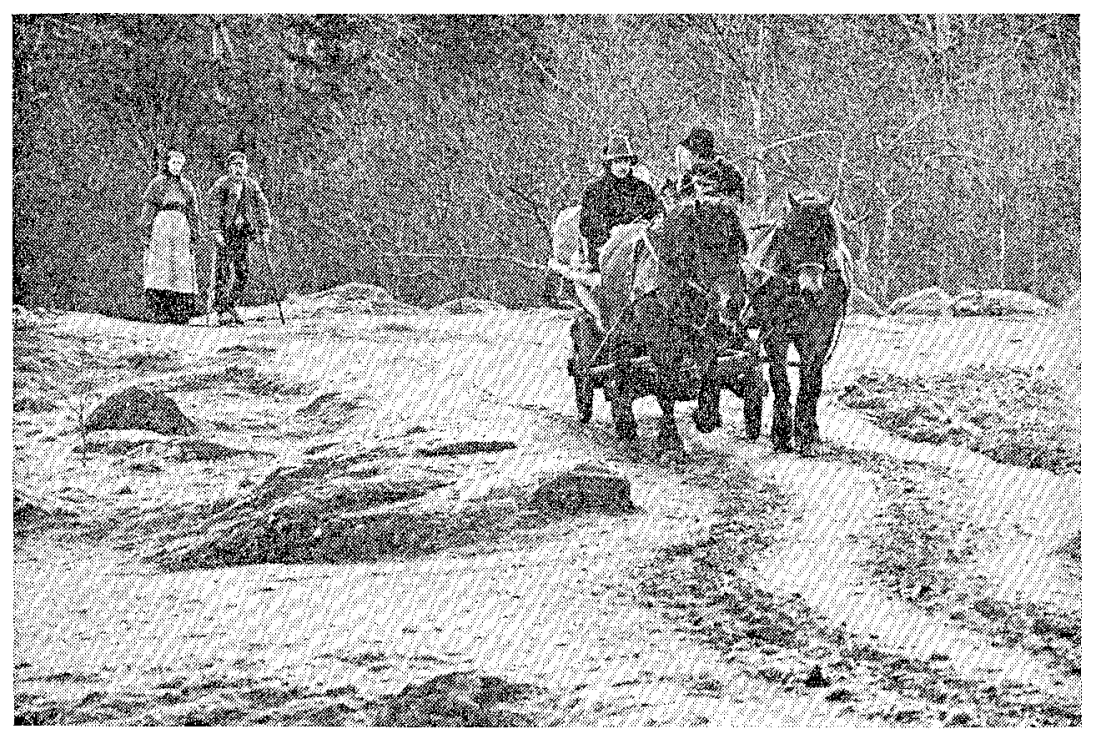

From the film 'The emigrants' - the departure. Emigrantinstitutet, Växjö.

Moves to new surroundings became common occurrences, no matter whether it concerned emigration to America or a move to find new means of livelihood in their own country.

Emigrants on their way to Gothenburg. Nordiska muséet, Stockholm.

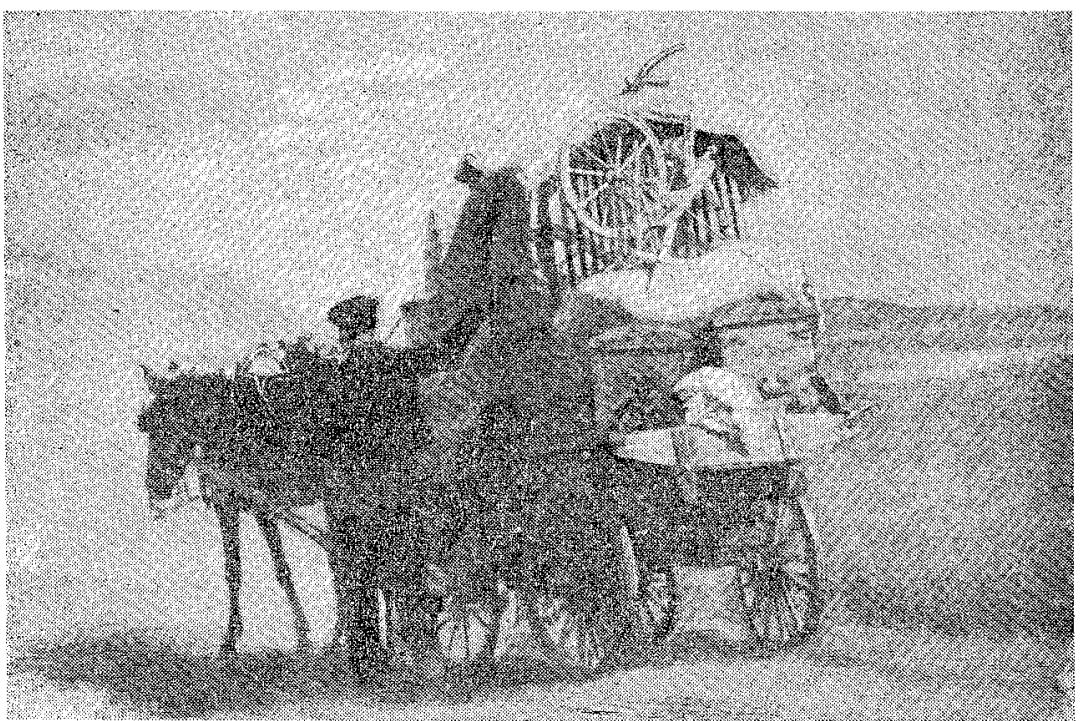

